\title{
Hip Hop Matters: Race, Space, and Islam in Chicago
}

\author{
Su'ad Abdul Khabeer \\ Purdue University
}

\begin{abstract}
In this article I examine pious Muslim placemaking against the backdrop of race and class tensions in the United States. I contend that ideologies of anti-Blackness converge with pious Muslim space and placemaking practices to create a moralized division of space for Chicago Muslims. Specifically, I look at the ways that pious Muslim placemaking in Chicago suburbs by Muslim immigrant parents is entangled in elisions of race and class in the US. I show that whereas a generation of Muslim parents pursued a pious Muslim life in proximity to a White, middle-class, American dream, groups of young Muslim activists are making Muslim space and place through Blackness in the 'hood. I argue that young Muslim activists embrace hip hop's remaking of space and place to remap the pious geographies of Muslims in Chicago and challenge conceptions of pious Muslim identity that are inflected with anti-Blackness. I demonstrate how these young Muslims find value in Blackness, as an ethic of social justice and an exemplar of Muslim piety, to contest hegemonic isomorphisms of race, space, place, and morality. Thus, I argue that by reclaiming and remaking space and place, young Muslims oppose anti-Black racism found within broader US society as well as within the entrenched divisions of pious Muslim space in Chicago. [Hip Hop; Race; Space and Place; Islam; United States]

\section{Introduction}

Fieldnote 2008:

This visit was so unlike the first; I was greeted and not just stared at. I was still 
one of the few non-Arabs, but folks were cool and welcoming. The youth are like that. ... I know people stare [at strangers] but being stared at that first time felt more like hostility than curiosity, [as if to say] "you're un-invited." I remember that night [of the second visit], it was warm. I asked Rabia if she wanted to come with me to the poetry café but she was like, "nah, son." It seemed like she shared my initial feelings about this organization; that it was not an inviting space unless you were Arab, or you were Latifah — so Rabia decided not to come. The evening probably started around 7:30 p.m. Last time I was there I was with Latifah and I helped her and the other youth make signs. The main area where we had worked on long folding tables was now filled with rows of folding chairs in two sections with an aisle down the middle. The signs we made now adorned the walls: "Ireland $(26+6=1)$," "Tengo Puerto Rico en Mi Corazon," "EZLN," 'New Black Panther Party," "Viva La Resistencia," and "In Commemoration of the Nakba." The two youth program coordinators, Fadi and Hala, opened the poetry café. They were funny and clearly used to being behind a microphone. Hala, in her twenties, is a long-time and deeply committed youth organizer. She engaged the crowd by asking which parts of the city they came from: "Is the Southside in the house?!" "Is the Northside in the house?!" At first, the crowd responded by raising their hands to indicate where they live. But Hala wanted a different kind of response, she asked again by shouting out: "This is $63^{\text {rd }}$ and Kedzie, we don't raise our hands, we shout and holla here!"

This is a passage from a fieldnote I wrote after I attended a youth poetry café at an Arab US American community-based organization on the Southwest side of Chicago, Illino is. Rabia, a 
Pakistani US American, and Latifah, a Black US American, were two college-aged Muslim women and among my key teachers (interlocutors ${ }^{1}$ ) during almost two years of fieldwork in Chicagoland (the city of Chicago and surrounding suburbs). I met them at another nonprofit in the same Southside neighborhood, the Inner-City Muslim Action Network (IMAN). IMAN was a central site of Muslim life in Chicago and consequently significant to my broader research on Blackness, hip hop, and Islam. ${ }^{2}$ The Arab US American nonprofit was a community institution for local Muslim Palestinian US Americans, most of whom had left the Southwest side of the city for the southwest suburbs in the last decade. Although neither Palestinian nor Arab, Latifah felt very welcome at the organization. She had deep relationships that spanned many years with the young Palestinian US Americans who were served by the organization's youth development programming. In contrast, despite the nonprofit's good and important work—particularly for working-class Palestinians-Rabia and myself, a Black Muslim woman, found the nonprofit to be a space that was unwelcoming to non-Arabs.

My very first visit to this nonprofit, a year earlier, was for a dinner it had hosted. The dinner, which I attended along with other IMAN staff and volunteers, was part of a move by the youth program coordinators of the Arab US American organization and IMAN's leadership to build stronger ties between the two nonprofits. The work of the two organizations overlapped; for example, both offered arts-based youth development programs. However, from my observations, they seemed to work more in parallel than together, and subsequently their staffs had little rapport with each other. At the time of my research, IMAN's small staff was predominately Black US American and Latinx ${ }^{3}$ and as we headed over to the Arab US American nonprofit, one IMAN staffer expressed some skepticism about whether or not the organization was really committed to building this kind of bridge between the two nonprofits. And when we 
arrived and were stared at, as described in the fieldnote above, I recalled his words.

The dinner had opened with a brief greeting in English by Hala, who was followed by a second speaker who explained that her speech would be in Arabic for the benefit of some of the older mothers in the audience. However, unlike what many seemed to have expected, this short speech, which expounded upon the programs offered by the organization, was not followed up with an English translation. The discomfort and dismay of IMAN folks in the audience was palpable and the choice not to translate seemed to underscore the feeling that the nonprofit was an exclusionary space. It also created an awkward moment for Hala who returned to the microphone and reiterated that the point of the night was to build relationships of solidarity. This move by Hala reflected the orientation of the Palestinian US American Muslim youth workers whom I had already met from this organization, who saw themselves as distinct from an older generation of workers. These youth workers were cognizant of the ways the organization excluded non-Arabs and therefore they emphasized connections across difference, particularly links between Palestinian and other freedom movements, in their own work and programming. ${ }^{4}$

The bulk of the organization's work centered on youth leadership development through art, specifically hip hop and spoken word poetry, which is a common practice at communitybased organizations in Chicago, as it is across the US (Clay 2012; Kwon 2013). This technique focuses on teaching youth to use art as a form of resistance to structural inequality at local and international levels. The signs the young people had created the afternoon before the café, which cited a broad range of liberation movements, illustrated this emphasis. Importantly, through this display of solidarity that evening at the poetry café, the youth spatially altered the nonprofit from a place that excluded to a place where many could feel welcome.

As my fieldnote indexed, these youth workers often consciously incorporated iconic 
notions of Blackness and space as rendered through hip hop to both create and affirm solidarities between Arabs and non-Arabs in their local community. The Southside location Hala invoked, "6 $3^{\text {rd }}$ [Street]," signifies space and place; more specifically, it conjures the "hood." For some, "6 3 rd, connotes Black and Mexican US American bodies amidst poverty and gang violencemarking the 'hood as a place you seek to escape from and, for those residents unable to move, as a place where life can be one of embattlement and injury (Ralph 2014). While statistical indexes do point to higher rates of crime and poverty in the 'hood, these "racialized connotations" are not merely based on demographic correspondences. Rather, they reflect racial ideologies of space and place in Chicago in which 'ubiquitous distinctions about 'neighborhoods' are virtually inseparable from their overt or submerged racial and also class-inflected meanings" (De Genova and Ramos-Zayas 2003, 32).

In contrast, Hala's invocation reframes $63^{\text {rd }}$ Street, and the 'hood more broadly, as a place of pride reflecting alternative forms of space and placemaking that come out of hip hop music and culture. Hip hop resignifies Black and Latinx urban communities as the 'hood. Hip hop acknowledges the injurious poverty in Black and Latinx urban communities, but also identifies other forms of wealth that circulate in the spaces and places of Black and Latinx life. This "new terminology and discursive frame" is local but also scales up to "address conditions in all 'hoods everywhere" (Forman 2002, 65). Hence in Hala's iteration-“This is $63^{\text {rd }}$ and Kedzie!”-poverty and violence inform but do not overdetermine the imagining of place. It is precisely because $63^{\text {rd }}$ is in the 'hood and not, for example, in a section of Chicago's predominantly White and wealthy Northside that Hala proudly asserts that "we don't raise our hands, we shout and holla here!" Likewise, the value that she recuperates for $63^{\text {rd }}$ Street extends to "all 'hoods everywhere" like those represented on the signs that adorned the walls of the nonprofit. 
In its reworking of space and place, hip hop operates epistemologically to "reorganize conceptions" of the self and the world in ways that "radically challenge sanctioned forms of knowledge" (Hill 2009, 121). From classroom pedagogies and White hip hop "heads" (aficionados) to Asian US American hip hop artists, hip hop's epistemological challenge serves as a guiding framework through which Black and non-Black youth interpret their social locations in the US racial order as well as vis-à-vis broader global dynamics (Kitwana 2006; Wang 2007; Nair and Balaji 2008; Hill 2009; Sharma 2010; Clay 2012; Peterson 2014). Hip hop’s epistemological challenge also extends to religious thought and practice. For example, Michael Eric Dyson (1997) and Anthony Pinn (2003) wrote against the presumption that rap music and religion are diametrically opposed; an opposition that nicely aligns with the sacred/profane binary of traditional religious studies. ${ }^{5}$ This and later work has shown that hip hop's relationship to religion is not reducible to strict adherence to religious tradition and institutional modes of piety or the lack thereof. Rather the "religious" in hip hop is found in the way the music "tackles questions of meaning, both existential and those of ontological weight" (Pinn 2003, 18). Further, this scholarship also attends to the ways that the spiritual in hip hop is not always a means to transcend the world but can in fact be a means for better access to the worldly (Sorett 2009; Utley 2012; Miller 2013).

Reconstructions of space and place also play a significant role in contemporary Muslim life. Muslim subjectivities, particularly under the rubrics of tradition and piety, have become key sites of anthropological inquiry (Asad 1986, 1993, 2003; Mahmood 2005; Deeb 2006; Hirschkind 2009; Schielke 2009; Grewal 2013). This diverse body of work provides complex accounts of Muslim subjectivity to both destabilize the universality of secular liberal notions of the self as well as to underscore how the formation of ethical Muslim selves relates to hegemonic 
global discourses (Deeb 2009). This line of inquiry also identifies piety as "inherently a bodily and spatial practice" (Jouili 2015, 161; emphasis added). Particularly in locales in which Muslims are a minority, such as Europe and the US, or a significant segment of a religious plurality, like Lebanon, space and placemaking practices play a significant role in the construction of pious Muslim identity.

In these contexts, Muslim spatial practice includes pious "micropractices" that challenge secular notions of space, place, and time, such as finding a secluded place to perform salat (daily prayer) on a university campus or in a workplace (Jouili 2015). Muslim piety is also made through grander forms of spatial appropriation such as parades that commemorate Sufi saints and sacralize presumably secular public space (Werbner 1996). Along with these liminal spatial practices, Muslims also build their own pious spaces and places, a "new sacred domain" constructed through "Islamic institutions, businesses, associations, and lifeways" that map onto the "multiple worlds already operating" in US and European cityscapes (Abdullah 2010, 108). Critically, the "virtues" of a pious Muslim landscape, what Deeb and Harb (2013) call the "Islamic milieu," are not predetermined. Rather, the spaces that Muslims build to enable the living of a pious life are negotiated, and "continually reconstructed and reproduced by various actors" who deliberate over ideals and values (Deeb and Harb 2013, 37).

In what follows, I examine pious Muslim placemaking against the backdrop of fissures of race and class in the US. I seek to contribute to anthropological thinking around space and place by linking the discussion of pious Muslim space and placemaking to theories of race and hip hop epistemology. In the contemporary moment defined by the overlapping contexts of postcoloniality, US imperialism, and the global Islamic revival, Muslim piety is defined by some Muslims, in part, by its contradistinction to "western" ideals. This tendency was replicated in the 
suburban placemaking of Arab and South Asian Muslim immigrant parents in Chicagoland who moved to the suburbs to facilitate their vision of living a pious Muslim life. Yet, when choosing the suburbs over the city, this pious placemaking is also entangled in spatial discourses of race and class in the US. Specifically, I argue that ideologies of anti-Blackness converge with Muslim space and placemaking practices to create a moralized division of space for Chicago Muslims.

Further, I illustrate how the young Muslim activists I worked with, many of whom are the children of these same immigrant parents, also engaged in pious placemaking that was shaped by issues of race and class, but interpreted differently. ${ }^{6}$ In this essay, I look specifically at IMAN's biennial festival, Takin' It to the Streets (hereafter referred to as Streets), to illustrate how my teachers used hip hop to construct spatial interventions. My young Muslim teachers drew on hip hop epistemology to disrupt dominant notions of Muslim identity by engaging alternative ways of self-making, spacemaking, and placemaking. They embraced hip hop's remaking of space and place that linked "'hoods everywhere," which had specific implications for how they engaged and remade the pious geographies of Muslims in Chicago. Whereas their parents pursued a pious Muslim life that is in proximity to a White, middle-class, American dream, young activists made Muslim space and place in the 'hood. Through hip hop spatial interventions, young Muslims challenged Muslim anti-Blackness as a means of constructing their own sense of piety and extending the geography of Muslim space and place in Chicago. By focusing on this intersection between race, space, and Islam, I demonstrate how notions of Muslim piety in the US are produced by, reproduce, and contest racial hierarchies in the US. Furthermore, I bring a critical race lens to important anthropological approaches to Muslim identity by illuminating how the practice of religion is informed by and reproduces the social construction of race and ethnicity, and likewise, how the lived experience of race and ethnicity is made to and through religious 
commitments.

\section{Race, Contested Moralities, and Chicagoland Islam}

Approximately 400,000 Muslims live throughout Chicagoland (Inskeep 2006). Chicagoland Muslims have roots in the Middle East, South Asia, West Africa, the Balkans, the Southern US, and the Caribbean, and hold religious orientations from the Nation of Islam (NOI) to Sunni and Shi'a orthodoxy. Muslims, who have made Chicago home since the early 1900s, live in communities segregated by race and class, reflecting the patterns of residential segregation Chicago is known for (Massey and Denton 1993; Pattillo-McCoy 2000; De Genova and RamosZayas 2003; Bogira 2011). Early on, Black US American Muslim Chicago residents built their own Islamic milieu within the city, yet since the 1980s most Muslim immigrants have looked toward the suburbs to build their homes and community institutions. For example, in 1969, a large, predominately South Asian US American mosque was established in a Northside Chicago neighborhood and twenty years later it opened a full-time Islamic school in a suburb just north of Chicago. Similarly, Muslim Palestinian US Americans have been residents of the Southside since the mid-twentieth century, but opened their parochial Islamic schools in the suburb of Bridgeview, Illinois in the 1980s.

The story of Huma, a young Pakistani US American, illustrates the placemaking practices of many Muslim immigrants in Chicagoland. I also met Huma at IMAN where she was a volunteer. She grew up in the predominantly Palestinian US American section of Bridgeview, which is home to two private schools, a large masjid (mosque), and more than one hundred businesses. Huma's parents moved to Bridgeview to raise their children around other Muslims. Huma explained that "they [South Asian and Arab immigrant parents] go and they find land, they build a mosque that's, you know, for the Muslims" to describe a strategy employed not only 
in Bridgeview but by many Muslim immigrants who seek to create spaces and places conducive to the construction of Muslim life similar to what they left, or imagine they left, "back home."7 She continued,

But the kids are born here. They are a part of that [the spaces their parents created] but then they start to go to [public] school or whatever and they have friends and it just, it clashes, right? And it was a problem, it was like I found myself wanting to be less and less Muslim because what I thought a Muslim was [is] this strict kind of person who is always praying, and you only eat certain kinds of food, you can't wear certain kinds of clothes, you can't hang out with certain people. ...

According to Huma, the Muslim places created by her parents' generation legitimated only very specific ideas of religiosity—what a Muslim can or cannot do, the people they can spend time with —in the pursuit of a pious Muslim life. Hence, although suburban masjids, homes, and schools are more spacious than those that remain in the city, for my teachers like Huma, they provided much less room for different expressions of Muslim piety.

Huma's reflection, “it just, it clashes, right?" can conjure a now-familiar notion of a clash between "US American" and "Muslim" identities. Yet I argue that the conflict at hand was not a clash of civilizations but conflicting conceptualizations of how to live a pious Muslim life in a US American context. For example, in her study on the global Islamic revival in the US, Grewal (2009) found that, in debates over interracial marriage, second-generation US American Muslims posed their own perspectives as "pure Islam" in contrast to their parents' "cultural" and ethnocentric marriage preferences. Yet as Grewal shows, this notion of "pure Islam" was in fact deeply reflective of these young Muslims' US "American sensibilities" that informed their 
criticism of their parents' race- and class-based prejudices (Grewal 2009, 325). In my own fieldwork, these dynamics of piety and generation were not explicitly described in terms of pure versus cultural Islam. However, my teachers did interpret Muslim piety along similar lines of ethical critique. For them, a pious Muslim was an ethical Muslim, specifically a Muslim who stood up for justice.

OmarMukhtar, also raised in Bridgeview, argued for an alternative construction of Muslim piety. OmarMukhtar was a young Arab man and IMAN volunteer who credited hip hop's epistemology with helping him understand his identity as a racialized subject in the US. He explained, "You just swap the word Black with Muslim or Palestinian [and] it all becomes very relevant. You start to attach the struggles together." Muslims, OmarMukhtar posited, should not focus on "dos and don'ts," but principles of truth and justice. Drawing on the model of the Prophet Muhammad and an ethos of the Five Percenters that he learned via $\mathrm{RZA}^{8}$, he contended, "If you can focus on these things - being passionate, truthful, honest, sincere, just - then your whole well-being and your whole understanding of the world is transformed." I argue that it is this kind of ethical conceptualization, informed by hip hop's epistemological challenge to US racial logics, that frames the self-making and placemaking practices of many young Muslim activists in Chicago. Importantly, my young Muslim teachers were not the only ones whose notions of Muslim piety were informed by their US context. Some of the pious spatial norms created by Muslim immigrant parents, like a gender-segregated youth recreation center, diverge from mainstream US American practice. However, the move to "go and find land" in the suburbs also reflects mainstream US American sensibilities around race, class, and space.

Arab and South Asian Muslim immigrants who moved to the suburbs to create Muslim space were also pursuing the "American Dream." Classically rendered through tropes of hard 
work and equal opportunity, attainment of the American Dream is measured by proximity to normative White symbols of success. These spatial implications of the American Dream underscore how "racism ... [is] the cornerstone of patterns of urban and suburban separation and exclusion" (Low 2009a, 80). The American Dream is idealistically realized in the suburbs, in proximity to Whiteness and far removed from the ghetto (i.e., Blackness), making the American Dream a racial one. I am not arguing that the move to the suburbs is a simple move toward Whiteness and assimilation-Muslim immigrants' construction of pious Muslim space also reflected their own ethnoreligious priorities. Rather, I seek to highlight how the construction of pious Muslim spaces aligned with White normativity in its relationship to Blackness. Thus, in the pattern of White suburbanites, when Muslim immigrants moved to the suburbs, they also moved away from Chicago's "Black Belt," and the suburban homes of many Muslim immigrants and their families are also equidistant from Chicagoland's Black middle class. ${ }^{9}$

However, it must be noted that while adopting ideologies of anti-Blackness is often a riteof-passage for immigrants to the US, as non-Whites, Arab, and South Asian US American Muslims have a complex relationship to Whiteness and Blackness. ${ }^{10}$ Huma also described how building Muslim spaces led to white flight: "The houses get sold really quick ... and if there are non-Muslims they'll move out 'cause they just don't want to be there." In her work on Bridgeview, Louise Cainkar documents White residents who saw Arab newcomers as "undesirable," "unwelcome," and "non-white invaders" (Cainkar 2005, 183). ${ }^{11}$ Racialized as "Brown"-neither Black nor White-Arab and South Asian US American Muslims are positioned as perpetual foreigners whose bodies and behaviors, particularly since $9 / 11$, stand as a "risk" to Whiteness (Razack 2008, 32). Thus, on the one hand, that which makes Arab and South Asian US American Muslims different, such as their religion, is a threat to "American values." 
Yet on the other hand, when this difference is viewed as form of "ethnic particularism" through food, music, dress, etc., it marks these Muslims as model minorities who juxtapose positively against Black "pathology" (Chan-Malik 2011).

Successfully avoiding Blackness through cultural distinction and residential distance reflects and reproduces religious hierarchies. Race and class are major fissures within the US Muslim community, specifically between the three largest ethnicities: Black, Arab, and South Asian US American Muslims. These fissures revolve around a discursive framework that marks Arab and South Asian US American Muslims as more religiously authentic and authoritative than Black US American Muslims (with Arabness being the marker of the most authentic authenticity). ${ }^{12}$ A Muslim of Arab descent, for example, is presumed to have proximity to the Islamic tradition simply because she has roots in the Middle East and, as a result, her religious practices and perspectives are endowed with authenticity and ethnoreligious hegemony. By contrast, a Muslim who cannot claim immediate descent from the "Muslim world," such as a Black US American, is always considered a (comparatively) "new" Muslim whose religious practices and perspectives have to be authenticated and are marginalized. These claims to proximity are a powerful form of cultural capital and power among US Muslims. This distinction, which operates discursively, also extends to evaluations of space and place. The values attached to certain Muslim bodies are also attached to the places and spaces they inhabit.

Linking specific values to specific bodies in specific spaces assumes an "isomorphism of space, place and culture" in which "peoples," their cultures, and the spaces and places in which they reside are configured as discreet and distinct wholes (Gupta and Ferguson 1992,7). Anthropologists are critical of this naturalized boundedness, as manifested in the discipline and beyond, because it does not accurately portray the interactions and flows of people, ideas, 
practices, and capital that are central to the production and reproduction of culture (Appadurai 1988; Rodman 1992; Low 2009b). Space conceptually enters this conversation through the work of Lefebvre (1991) who identified its key role in the production and reproduction of social relations, which includes both the maintenance of hegemonic power and symbolic resistance to it. Drawing on Lefebvre, anthropology has come to see space as socially constituted through the interplay of the built and natural environment, the representation of space, and spatial and embodied practices (Jackson 2003; Low and Lawrence-Zuniga 2003; Davila 2004). This theory of space emphasizes space as more than a backdrop; rather, space is seen as foundational to the formation of cultures and identities. Alongside Lefebvre, other theories of space (Bourdieu 1977; De Certeau 2011) also pay attention to the ways that space's meaning is tied to practice to underscore how people use space to produce and reproduce, as well as contest and remake, social behaviors, social relations, and cultural forms. The meanings humans endow in space through its "social construction" (Low 2000) "[transform] space into [the specificity of] place" (Low and Lawrence-Zuniga 2003), and this specificity, as Gupta and Ferguson (1992) emphasize, is always tied to power. Hence rather than different, distinct, and disconnected, people, cultures, and spaces are interconnected by "hierarchal power relations" and it is through these power relationships that "space achieves a distinctive identity as a place" (Gupta and Ferguson 1992, 8).

In the US, power hierarchies of race and class manifest in discourse, policy, and planning, and broad structural inequality marks the identities of places such as cities and suburbs. The suburb is the location of the home, safety, order, and normative Whiteness, and the city, specifically the 'hood, is a symbol of danger, disorder, and Black pathology. The Muslim spatial patterns described above reproduce these racialized connotations of city and suburb. Therefore, while facing racial discrimination because they are "Brown," the Muslim immigrants' move 
toward the suburbs also reproduces the racialized ways US Americans perceive and experience social mobility and define what places are desirable and how those places are protected and preserved (Gregory 1999).

Significantly, these identities of place are made through unequal power relations and contested moralities in which "space and place are... widely conceived of as metaphors for, and metonymic extensions of, culture, moral virtue, identity, truth, hegemony, and subordination" (Werbner 1996, 309). Moreover, the relationship between power, morality, space, and place is not unidirectional; rather, "morality and geography are dialectically interdependent and shape one another" (Deeb and Harb 2013,10). As the experience of space and place shapes notions of morality and vice versa, moralities are debated and negotiated. Accordingly, the moral geographies of those with power, whether a nation-state or, in the case of my fieldwork, a generation, do not go uncontested but vie with alternate moral mappings of space and place (Grewal 2013). As Vasquez and Knott note, "religion provides the resources to craft moral and affectively charged maps that not only reflect and buttress the logic of spatial regimes, but may also offer tools to challenge them, to introduce heterogeneity by building alternative utopias" (2014, 327).

During my fieldwork I found these competing articulations of the relationship between morality and geography among Chicagoland Muslims. Among Arab and South Asian immigrant parents "spatial practice made sacred" (Knott 2005, 159) the distinction between the city and the suburb as it mapped other conceptual binaries: Muslim-non-Muslim, piety-impiety, and religious authenticity-inauthenticity. Within the context of the hierarchical power relations of race in the US, these moralistic distinctions overlapped with racialized connotations of place in which the danger, disorder, and Blackness of the 'hood mapped it as an unsuitable space for the 
construction of Muslim places. In this spatial calculus there were some instances in which the 'hood, as a place, could be tied to Muslim piety_namely as a site of charitable service and therefore a place to perform piety. Yet even in these instances the 'hood did not emerge as a locale from which Muslim authenticity and piety springs.

It was a common complaint among Muslims who lived within the city limits, particularly Black and Latinx Muslims, that religious life was concentrated in the suburbs, from Islamic schools, religious classes, and lectures by prominent scholars, to Eid celebrations, ${ }^{13}$ fashion shows, and concerts. These dynamics also shaped my fieldwork experience in Chicago. I lived on the Southwest side near IMAN and while IMAN events were a quick ten-minute drive, I spent a lot of time in my car (and in traffic) going to the suburbs for events - a lecture on Muslim youth by a prominent scholar held in the western suburbs, an Arabic class Rabia attended in the northern suburbs, and driving southwest to Bridgeview to purchase tickets for a fundraising nasheed (Muslim praise music) concert that was held in the northwest suburb of Rosemont. Muslim spaces and places in the suburbs functioned as "ethnic Muslim space," which Jamillah Karim defines as "spaces where one [Muslim] ethnic group dominates" (Karim 2008, 54). Here, dominance of one group is more about norms than numbers. In Chicago, ethnic Muslim space describes a qualitative experience in which unequal power relations render many Muslim spaces as places where Blackness is unwelcome. Thus, while the location of these institutions and events was concurrent with the residential patterns of the Muslim communities they served, it is my contention that the spatial patterns of pious Muslim life reflected and reproduced racialreligious hierarchies.

The young Muslims I worked with intentionally bridged these racial and spatial religious divides. Many within my core group of teachers did not live in IMAN's neighborhood but in the 
suburbs or suburban-like edges of the city. Yet when they left the "'burbs to 'kick it' in the city," as one Black US American youth, Khadijah, put it, they did not drive in to shop on Michigan Avenue, sneak into a club, or even take in high art, but to participate in hip hop-based activism as Muslims. Through their travels across space they complicated certain normative associations between morality and geography among Muslims in Chicago, and challenged Muslim antiBlackness. Specifically, they used hip hop to mark space in a different way; unlike immigrant parents, they did not reject the city but moved toward it, thereby contesting the moral geographies mapped by this parent generation. Whereas the suburb was the place where immigrant parents' values could be protected, it was in the 'hood that my young Muslim teachers' values were discovered, determined, and discharged.

\section{Takin' It to the Streets: Blackness, the 'Hood, and Ummah Space}

As noted in the introduction, space and place have long been critical categories in hip hop. Broad public and private disinvestment alongside massive urban planning remapped the South Bronx of New York City, which was home to the Black and Latinx communities who gave birth to hip hop (Chang 2005; Rose 1994). ${ }^{14}$ These large-scale changes resulted in high rates of unemployment and distressed living conditions that would be captured in the earliest hip hop songs. ${ }^{15}$ Yet hip hop also shaped the lived environment. Early hip hop artists and promoters appropriated public spaces like recreational parks to host "jams" that introduced audiences to hip hop music and facilitated the reproduction of hip hop culture. As Forman argues, much like Hala's invocation of $63^{\text {rd }}$ Street, hip hop advances a discourse of "cultural recuperation" that expunges the negative associations of the "ghetto," now renamed the "hood," while keeping the places of Black and Latinx life intact (Forman 2002, 65).

Importantly, hip hop's reworking of space and place can also operate as a 
deterritorialized spatial imaginary. Tracking the work of popular hip hop artists, Sean "Diddy" Combs and Ma\$e, Jackson Jr. (2003) demonstrates how the hip hop conception of "Harlemworld" is not a literal rendering of Harlem as the present-day 'hood, but rather of the 'hood in past tense. In this rendering, socioeconomic mobility out of the 'hood rather than immobility tied to the 'hood is central to the identity of place and individual belonging in Harlem. Hip hop's spatial imaginary also takes shape in the notion of the hip hop community as a "nation" in which "an ideology of nation-consciousness and nation-building shapes the actions of those involved in" hip hop music and culture (Alim 2006, 38). Critically, Alim argues that hip hop nation-building is a threat to "the ruling class and their ideas" (Alim 2006, 22). Like the signs that covered the walls of the poetry café, as a nation, members of the global hip hop community do not see themselves bound to the territorial borders of official nation-states, but make connections between their local conditions and that of others (Mitchell 2002; Swedenberg 2010; Pardue 2011).

IMAN explicitly takes on hip hop's spatial imaginary. By foregrounding the "Inner-City" in its name, the nonprofit signals the centrality of the 'hood to its mission. IMAN conceives its local neighborhood and the 'hood more broadly as culturally rich, and its initiatives include providing services to its poor and working-class neighbors and community organizing with residents around the social and economic justice issues most affecting the neighborhood. Further, because IMAN works within the 'hood, race and Blackness are also key categories of significance. IMAN designs arts events and activities for Muslim audiences to draw them to the 'hood to contest implicit negative associations that are made between Blackness and the 'hood in general discourse, which overlap with anti-Black racism and ethnocentrism in US Muslim communities. The organization attempts to disrupt the norms of ethnic Muslim space by 
employing staff and engaging volunteers, most of whom are Muslim, and (since I began my research) this pool of staff and volunteers has grown to be more ethnically and socioeconomically heterogeneous. IMAN is no racial utopia but it is well known for its aspiration to create diverse Muslim spaces: "[few Muslim] organizations demonstrate substantial inter-ethnic relations, but one group that comes close to this ideal is the Inner-City Muslim Action Network" (Karim 2008, 15).

In the fall of 2006, I met Rami Nashashibi, IMAN's Executive Director who was in his early 30 s at the time, at a meeting of young US Muslim leaders. We discussed our mutual projects: his on "ghetto cosmopolitanism"16 and my own interest in hip hop and young Muslims. Nashashibi suggested that IMAN's work directly related to my interests and invited me to begin my fieldwork as the event coordinator for Streets '07. Since the first festival in 1997, Streets has become one of the largest community festivals in Chicago and draws crowds from around the country. Streets takes place in a Chicago city park, Marquette Park, where Dr. Martin Luther King Jr. marched to protest residential segregation and was greeted with "rocks, bottles and firecrackers" (James 1966). The neighborhood surrounding Marquette Park is no longer predominately White, but Black US American and Mexican US American. Nevertheless, the same links between residential segregation and racial inequalities continue to prevail in the neighborhood and throughout the city. Continuities between the past and the present make this site a symbolically meaningful location for IMAN and its vision for Streets.

IMAN's staff and volunteers often described Streets as the embodiment of the organization's vision of a US Muslim community that is critically engaged (Nashashibi 2005). At IMAN, critical engagement meant US Muslim involvement and leadership in confronting social justice issues, and because of IMAN's commitment to the 'hood, racial hierarchies and the 
systemic inequality that these hierarchies produce were seen as the most paramount issues for Muslims to address. Importantly, as articulated by OmarMukhtar, from IMAN's vantage point this kind of engagement was predicated on developing a certain kind of ethical disposition toward justice as Muslims. Epitomized in Streets, but embodied in all its work, IMAN aimed to teach Muslims that standing up against racial injustice was central to their piety, and thus at the core of this ethical pedagogy was the undoing of anti-Black racism in Muslim communities.

The theme of Streets '07 was "Ten Years of IMAN: A Celebration of Hope," which had a double meaning for those involved. The acronym IMAN is also an English transliteration of the Arabic term that means faith and belief. Hence, for folks at IMAN, Streets is a celebration of the organization but also a Muslim identity that is not confined to the racialized spatial imaginary of the American Dream nor the parallel spaces created by ethnoreligious hegemonies of Arab and South Asian US American Muslim communities. Rather their faith is in social justice, the transformative power of art, the ethical significance of Black Islam ${ }^{17}$ and hip hop, and the centrality of all of these to their notions of Muslim piety. This was the meaning that young Muslim activists tried to convey through all the spaces and places constructed that day. In contrast to an Islamic milieu built in the suburbs and, as a result, built away from Blackness in order to protect Muslim identity, these young Muslims built toward the 'hood and Blackness to expand the spaces and places of Muslim life. To illustrate the centrality of these themes, I offer the following virtual tour of Streets ' 07.

Volunteers clad in "Streets Crew" T-shirts met those who entered Marquette Park off $67^{\text {th }}$ Street. These "day of' volunteers numbered close to one hundred. They were mostly collegeaged, Arab or South Asian US Americans who were raised Muslim in the suburbs of Chicago. They gave effusive welcomes since they came to be part of IMAN's work, having been inspired 
by Nashashibi's rousing speeches. Once past the welcoming committee, festivalgoers walked to activities and events along Mann Drive, a paved two-lane road closed to cars for the day. To the east was the international bazaar, food vendors, a girls' Double Dutch competition, and a children's carnival space with inflatables, rides, storytelling, African drumming, and Aztec dancers. To the west was the first aid tent, free health screenings, and the three-on-three boys' basketball tournament, which Shareef Abdur-Rahim from the Sacramento Kings joined for the final game. Further west across Kedzie Ave at the park's field house were women's volleyball and basketball tourneys and a community gardening project at a nearby elementary school. Behind the carnival was a prayer area fitted with plastic colored carpets angled in the direction of Mecca and open all day for those unable to make the congregational prayers announced by the call of the adhan on the Main Stage near Kedzie Avenue. Not far from the prayer area was the Outreach Stage that held panel discussions on race, gender equity, and social justice, geared toward Muslim spectators.

Walking east and west on Mann, it was clear that Streets '07 was bookended by hip hop. On the east side was the Hip Hop Elements Stage. There, hungry novices as well as experienced emcees (rappers), which included male and female Muslim artists, "blessed the mic." DJs spun tracks and there was a cipher (a competitive circle) around a square of linoleum (expertly secured over grass) where bboys and bgirls showcased their dance skills. Graffiti artists were onsite, drawing on the energy of the crowds to create new art "live and direct." A skateboard ramp was also built at the Elements Stage, which was a nod to hip hop artist Lupe Fiasco's challenge to the stereotype that hip hop and Black youth have very narrow interests - namely sex, drugs, and violence.

At the other end of the drive was the Main Stage where around ten thousand made 
"hegira" at the end of the festival day. Many had come, from all over the city, to see Lupe, a Chicago native and a Black US American Muslim. The concert's prelude was a rally that featured a series of speakers, including the Harlem-based "hip hop Imam" Al-Hajj Talib AbdurRashid, a local Palestinian US American religious leader and a Harvard-trained Black US American Muslim woman historian. The concert itself had a lineup of hip hop legends - the Rock Steady Crew and Ali Shaheed Muhammad — and also featured a tribute to Afrika Bambaataa, as well as musical sets by newer artists. ${ }^{18}$ Preachers, scholars, and artists alike riffed on the historic relationship between Blackness, Islam, and hip hop to underscore the transformative power of art and the urgency of social justice. Their presence and performances brought Streets' spatial intervention in anti-Blackness among US Muslims that day to a close. Streets enacts overlapping spatial interventions. IMAN's decision to hold Streets in a park on the Southside rather than, for example, at Millennium Park in Chicago's city center is deliberate. By staging the festival on the Southside since 1997 (the most recent Streets was in 2016), IMAN recuperates the 'hood. This spatial move challenges anti-Blackness embedded in popular elisions of race, space, and class in the US and, likewise, it challenges US Muslim antiBlackness to remap the 'hood as a place of value for Muslims. In part, the 'hood in IMAN's spatial imaginary is valuable because of the diverse mix of Muslims that attend Streets. This diversity comes as part of IMAN's concerted effort to bring Muslims to the park (an effort that includes chartering buses that run from suburban masjids to the festival) so that the 'hood becomes a site for the enactment of critically engaged pious Muslim life. In many ways, through these efforts, Streets functions as a prototypical ummah space. In contrast to ethnic Muslim space, Karim theorizes "ummah space" as the space "in which Muslims live out the complexities of ethnic Muslim identities as they sometimes reach ummah ideals" (Karim 2008, 13). Ummah is 
an Arabic term that translates as "community" or "nation," and ummah ideals, derived from Muslim understandings of the Qur'an and the prophetic tradition, are of egalitarian and mutually interdependent relationships of brotherhood and sisterhood among Muslims worldwide. Yet for IMAN, bridging racial and ethnic divides to construct ummah space does not make race irrelevant for Muslim piety. The 'hood is also valued because it has a relationship to Blackness, yet here Blackness does not signify pathology, but an ethic of social justice. Accordingly, the move to value Blackness and the 'hood is a move for expansion and engagement rather than exclusion.

My teachers came to see Blackness as an important index of social justice through their engagement with the messages and icons of hip hop music and culture. The hip hop generation locates itself within a genealogical connection to the civil rights and Black Power eras (Clay 2012) and thus often defines itself as a continuation of these earlier struggles against systemic inequality. They construct a political genealogy by drawing inspiration from icons of the Black Radical Tradition like Malcolm X-who is often sampled in hip hop music — as well as reviving the use of arts in consciousness-raising and mobilization efforts like the Black Arts Movement. This genealogy was doubly significant for my teachers who, as Muslims, saw icons like Malcolm $\mathrm{X}$ and Muslim artists like members of The Last Poets as their predecessors in activism and faith.

The full name for the Elements Stage at Streets '07 was 'Hip Hop Elements Stage: From Mecca 2 Mecca," and organizers described it as a "space for artists and others to nurture a positive movement toward the reclamation of socially conscious hip hop" (Inner-City Muslim Action Network 2007). The Meccas that participants were meant to "travel" between were the hometown of the Prophet Muhammad—Mecca, Saudi Arabia—and a hip hop hometownHarlem, New York. ${ }^{19}$ Islam, specifically as practiced among Black US Americans, has made a 
profound impact on hip hop music and culture. Since the NOI inspired Afrika Bambaataa to unite street gangs under the banner of the Universal Zulu Nation, the hip hop community has taken up ideals of self-determination, self-knowledge, and political consciousness from the antiracist cosmologies of Black Islam (Chang 2005, 100). Importantly, this relationship is not unidirectional and scholars have shown that, along with the influence of Islamic theologies in the development of hip hop, hip hop plays a role in the construction of Muslim religious identity and in Muslim negotiations of national belonging in the US and beyond (Spady and Eure 1991; Swedenberg 1997; Floyd-Thomas 2003; Alim 2006; Miyakawa 2005; Taylor 2009; Gazzah 2010; Daulatzai 2012, 3; Aidi 2014).

In the imagined movement between Meccas, the Elements Stage functioned as an embodied space in which the dialectic relationship between Islam and hip hop took material and spatial form (Low 2009b). The Elements Stage showcased the artistic elements of hip hop, emceeing, dance, DJing, and graffiti, as well as what is known as hip hop's fifth element, knowledge of self, through its reclamation of socially conscious hip hop. Drawn from Black US American Muslims and expounded upon throughout hip hop communities, knowledge of self (which is a term directly taken from the NOI) refers to ethics of self-determination, selfknowledge, and political consciousness. Knowledge of self is a guide for ethical self-making in hip hop communities that is often manifested in hip hop culture through references to Islam and Muslims such as: citations of Muslim beliefs in hip hop music, the proliferation of certain Muslim practices within hip hop communities (including conversion to Islam for some), and stylistic choices such as knitted kufi caps. Moreover, knowledge of self in hip hop is a form of ethical "world-making" that is symbolically embodied in Black US American Muslims icons such as Malcolm X and Muhammad Ali. 
At Streets, and for IMAN more broadly, Black US American Muslim concepts, practices, and leaders heralded in hip hop are also configured as an ethical fountainhead. They are identified as a standard for a critically engaged and multiethnic US American Muslim community. Subsequently, Muslim placemaking by my young Muslim activist teachers was made through Blackness, not as opposed to or despite it. Streets was a space that encouraged racial inclusion by valuing Blackness and holding up the Black US American Muslim, rather than the Arab or South Asian US American Muslim, as the Muslim exemplar. This understanding and engagement with Blackness is an articulation of what Nitasha Sharma identifies as a "global race consciousness" that extends "the meaning of Blackness beyond biology" (Sharma 2010, 230). Sharma argues that for her South Asian US American hip hop artist interlocutors, Blackness operates as "a matter of critical understanding" that prompts an awareness of "how racisms impact interminority relations" (Sharma 2010, 2). Further, through Blackness and hip hop, these artists contest the model minority archetype-rather than aiming to assimilate to White normative ideals, they challenge the racial privilege of Whiteness (Sharma 2010). In a different context, the Brazilian hip hop community, Burdick (2013) also identifies the meaning of Blackness beyond biology: as an opening rather than enclosure. He argues that Black Brazilian gospel hip hop artists use their music to raise awareness of class-based marginalization and challenge essentialist ideas of Blackness in the Brazilian context. Harkening to Jackson's (2005) concept of racial sincerity, their challenge to Black essentialism is not a denial of their Black identities. Rather, they argue that their experience as Black people connects them to other marginalized groups, Black and non-Black, because it cultivates an "inclusionary impulse, a capacity to empathy, an ability and willingness to feel the pain of others" (Burdick 2013, 102).

Likewise for my teachers, Blackness was a means to understanding the self and 
connecting to others. They embraced hip hop's epistemological challenge to build connections to the 'hood and Black Islam that go beyond crass appropriations in which Blackness and cool are synonymous and where hip hop is a liminal site for youthful exploration and abandonment. My claim that my teachers' engagement "goes beyond" is not meant to imply that the tensions of cultural appropriation are completely evacuated in their activism as well as the spaces and places they construct. Indeed, for some of the "day of" volunteers, Streets was a kind of "hit-and-run feel-cool" form of activism. The specter of the "racial politics of cool" (Maira 2008) never vanished, but these politics did not overdetermine their relationship to hip hop, Blackness, and the 'hood; neither for IMAN as an institution nor for non-Black US American youth workers like Hala, Huma, and OmarMukhtar who make deep commitments of time and energy to social justice activism. ${ }^{20}$ Interactions with real-life Black people in activist projects that directly confronted the violence of racism helped to prevent the flattening of Blackness in my non-Black teachers' own consciousness. Furthermore, they configured the 'hood as more than a site for pious service but, through the ethical model of Black US American Muslims, Blackness, the 'hood, and hip hop became central components in their construction of an ethical Muslim piety.

\section{Hip Hop Matters}

By engaging hip hop epistemology, young Muslims in Chicago are reorganizing conceptions of pious Muslim space and place. They are departing from conceptions of the Muslim self and space that are entangled in logics of anti-Blackness. In the course of my fieldwork, young Muslims like Hala intervened by taking on hip hop's remaking of space and place to invert the meaning of " 63 rd, and the flattening of the humanity of the Black and Latinx youth who give life to hip hop music and culture. This flattening circumscribes not only the reach of hip hop but the possibility to recognize that these same Black and Latinx youth have and do make contributions 
of significance to "all 'hoods everywhere" - that is, the world. ${ }^{21}$ Furthermore, in the way she and the other young people worked to transform the Arab US American nonprofit from an exclusive to a more inclusive place challenged the hegemonies of her own ethnoreligious community. Likewise, by contesting racial hierarchies of space and place, IMAN reclaimed the 'hood as ummah space. Streets '07 challenged the exclusionary norms of ethnic Muslim space by bringing links between Islam, hip hop, and Blackness into material and spatial form in the 'hood. Both IMAN and Streets '07 remade the pious Muslim landscape by claiming the value of the 'hood and Blackness for Muslim piety.

Over the last decade since Streets '07, IMAN and the young Muslims involved in its work continue to be leaders in this spatial practice. However, now they are no longer alone. While the Arab US American community-based organization mentioned at the beginning of this essay continues to primarily serve the needs of the local Arab US American community, the efforts of youth workers like Hala have deepened its relationship with non-Arab and non-Muslim groups, especially around shared concerns like public education and police violence. Additionally, other Muslim organizations have chosen the city rather than the suburb as their homes.

For example, the San Francisco Bay Area based nonprofit, Ta'leef, officially opened its Chicago campus in a predominately Latinx Southside neighborhood in November 2016. From 2012 until the organization secured this Southside home, Ta'leef held religious classes, led by one of its Black US American founders Usama Canon, and other pastoral services in rented spaces throughout the city of Chicago. Ta'leef considers itself a 'third space" with inclusion and Muslim piety as core parts of its identity - its tagline is a quote from renowned Black US American Islamic scholar, Imam Zaid Shakir: "Come as you are . . to Islam as it is." Although 
founded in the Bay, there are close relationships between Ta'leef and IMAN such that Ta'leef's Chicago leadership includes former and current IMAN staff and volunteers. Moreover, while it does not offer arts programming, Ta'leef's discourse of Muslim piety embraces hip hop and Blackness. Accordingly, Ta'leef's choice to locate its temporary home within the city of Chicago and its permanent home in a community of color on the Southside is an extension of my teachers' spatial interventions.

As described earlier, anthropologists have charted the ways transnational, national, and local discourses inform the construction of Muslim piety. My examination of the construction of pious Muslim space in Chicago enriches this work by demonstrating the key role of national and local ideologies of race and class and hip hop epistemology in shaping competing ideas of pious Muslimness in Chicago. By bringing critical race studies to the anthropological study of Muslim piety, I illustrate that efforts to construct pious Muslim life are not defined only in how they diverge from "western" norms but also how they can and do integrate "western" ideologies-in this case, anti-Blackness. Additionally, I show how alternative understandings of race and Blackness also play a role in the cultivation of pious Muslim identity. By reclaiming and remaking space and place, young Muslims spatially oppose racist norms, specifically anti-Black racism found within broader US society and in the entrenched divisions of space for Muslims in Chicago.

\section{Notes}

${ }^{1}$ In this article I refer to my interlocutors as teachers because I drew on their generous sharing of their knowledge and experiences in coming to my own research conclusions. I use the term Black US American to refer to Black people who live in the US. This designation includes Black individuals who are recent immigrants from Africa; however, the majority of my Black US 
American interlocutors in Chicago were not of recent immigrant origin, whether from the continent of Africa or from other parts of the Americas. I also use the term US American to describe individuals and communities that live in the United States, in recognition of the fact that the United States is one country of many in the Americas.

${ }^{2}$ My formal research included twenty months of anthropology dissertation fieldwork in Chicago (from early 2007 to late 2008) and subsequent participant-observation research and interviews in Chicago, New York City, the San Francisco Bay Area, and the United Kingdom (2010-2015). In the field I had two core groups of interlocutors. The first group comprised eighteen-to-twentytwo-year-old youth leaders in arts-based social activism, primarily at IMAN. However, like Latifah, they also participated in youth organizing activities at other youth-oriented community organizations on the Southwest side. My interlocutors were Black, South Asian, and Arab US Americans who were primarily Sunni Muslims, and almost all were born in the US to Muslim parents. With them, I conducted participant observation, structured interviews, unstructured interviews, and focus groups. I also spent time with key teachers at their homes and schools, at youth organizing meetings, and at a range of other activities. The second group was a slightly older cohort of young adults in their late twenties and early thirties, whom I also engaged through participant observation, interviews, and a focus group. Alongside my interactions with these two groups of teachers, I interviewed parents and older community figures who played important leadership roles in the Chicagoland Muslim community. I also attended a broad range of events - including banquets, fundraisers, fashion shows, rallies, lectures, conferences, and jummah prayers (weekly Friday congregational prayers) - in the Black, South Asian, and Arab US American Muslim communities of Chicago.

${ }^{3}$ Latinx is a gender-neutral term for people who hail from Latin America and the Spanish- 
speaking Caribbean; it is used as an alternative to the gender binary of Latino and Latina.

${ }^{4}$ As I note in my conclusion, in the ten years since the visits described here, the organization has moved closer and closer to fully embracing the work of interracial solidarity championed by these youth workers.

${ }^{5}$ Of course, this claim extends to all of hip hop music's elements, not just rap. Rapping or emceeing is just one of hip hop's elements. Others include: dance, DJing, beatboxing, and graffiti.

${ }^{6}$ Although I conducted ethnographic research with a multiethnic cohort of young Muslims, in this essay I focus more specifically on the narratives of my non-Black interlocutors. I do so because of the ways their stories amplify young Chicago Muslims' move toward the 'hood and their challenge to anti-Blackness.

${ }^{7}$ For some, at least initially, Muslim space in Chicago was only meant to be temporary until they could return to their nations of origin. On the Bridgeview community, Cainkar explains: "the dream of most early Palestinian immigrants was to work hard, save money, and retire under their grape arbors in Palestine. Many never saw this earthly dream fulfilled. They were instead buried in the Muslim section of Evergreen Cemetery at 8700 South Kedzie Avenue" (Cainkar 2005, 188).

${ }^{8}$ RZA is a hip hop artist, producer, and one of the founding members of the group the Wu Tang Clan. RZA and many members of the Wu Tang Clan are part of the Five Percent Nation of Gods and Earths (NGE). The NGE spiritual movement was founded in the late 1960s by Clarence 13X, later known by the title Father Allah, who was formerly a youth minister in the Nation of Islam. Father Allah used the "Lost-Found Muslim Lessons," which make up what scholars refer to as the NOI catechism, in the expansion of his own spiritual teachings. Some Five Percenters 
consider themselves Muslims whereas others understand themselves to be at a higher stage of spiritual enlightenment. This part of my interview with OmarMukhtar also appears in Khabeer (2016).

${ }^{9}$ In 2000, Black residents made up fifty-two percent of the population of the south suburbs, which comprises "thirty communities directly south of Chicago" (South Suburban Housing Center 2008, 2). In contrast, the Southwest suburbs, the twenty-three communities west of the south suburbs where the village of Bridgeview is located, is an area "traditionally perceived to be 'closed' to African-Americans who comprised at the 2000 census, only 3.4 percent of the population" (South Suburban Housing Center 2008, 3).

${ }^{10}$ It should be noted that the anti-Blackness learned upon arrival in the US may also be reminiscent of anti-Blackness found in home countries. As Curtis (2014) describes, Black is a derogatory term in the Arab world due to the association between Blackness and slavery since the seventeenth century, and the Siddi minority group, who descend from free and enslaved Africans brought to pre-colonial South Asia, face racial prejudice today. Likewise, scholars of South Asia point to the influence of British colonialism in shaping anti-Black attitudes in the region (Sharma 2010, 30).

${ }^{11}$ Other Chicago Muslim suburban communities have faced stiff opposition to their efforts to build Muslim space in the suburbs. For example, a mosque built in the Orland Park suburb of Chicago faced complaints that building the mosque was "bringing terrorism" to "our backyards" (Parsons 2011).

${ }^{12}$ Sherman Jackson identifies this phenomenon as Immigrant Islam (Jackson 2005).

${ }^{13}$ Eid ul-Fitr and Eid al-Adha are religious festivals to celebrate the end of the fasting month, Ramadan, and commemorate the hajj (pilgrimage), respectively. 
${ }^{14}$ Robert Moses, the urban planner, spearheaded the execution of public works projects-from numerous parks, beaches, dams, the Triborough Bridge, and roadways to John F. Kennedy Airport - that reshaped New York City, most often to the detriment of poor and working-class communities. Moses' plan for the Cross Bronx Expressway, that used federal law to designate South Bronx neighborhoods as "slums," had the most direct effect on the areas that would become the ancestral grounds of hip hop (and perhaps, in an ironic way, the expressway should be considered hip hop's first monument). According to Jeff Chang (2005, 13-14), the South Bronx "lost 60,000 manufacturing jobs, the average per capita income dropped to 2,430, just half of the New York City average ... [the] youth unemployment rate hit 60 percent, and slumlords hired rent-a-thugs to burn [apartment] buildings to collect 150,000 on insurance policies ... [leading] to the loss of 43,000 housing units.” See also Rose (2009).

${ }^{15}$ For example, in the early hip hop classic, "The Message," Grandmaster Flash rhymes:

Broken glass everywhere

People pissing on the stairs you know they just don't care

I can't take the smell, I can't take the noise

Got no money to move out, I guess I got no choice ...

It's like a jungle sometimes it makes me wonder

How I keep from going under

(Grandmaster Flash and the Furious Five 1982)

${ }^{16}$ See Nashashibi (2007).

${ }^{17}$ By Black Islam, I refer to the range of expressions of Islam that have been significant in urban Black communities since the twentieth century, and I underscore the specificity and centrality of Blackness to the relationship between Islam and hip hop — namely, Ahmadiyya Muslim 
Community of the United States, Moorish Science Temple, the NOI, and even NGE, as well as the Sunni and Shi'a traditions. The groups I place under the rubric of Black Islam fall within and outside of traditional notions of Islamic orthodoxy yet remain critical to the construction of Muslim space through hip hop done by my young Muslim interlocutors. In their personal theology, my interlocutors adhered to normative standards of Sunni or Shi'a orthodox belief yet they also identified with the various traditions of Black Islam, including those that were neither Sunni nor Shi'a, as legitimate resources to draw on for ethical self-making as Muslims.

${ }^{18}$ Rock Steady Crew is the oldest hip hop dance crew, Ali Shaheed Muhammad is a member of A Tribe Called Quest, and Afrika Bambaataa is heralded as one of the "godfathers" of hip hop.

${ }^{19}$ The NGE refer to Harlem as Mecca.

${ }^{20}$ In Khabeer (2016), I also attend to the ways young Black US American activists interact with the racial politics of cool.

${ }^{21}$ After all, "the world is a ghetto" (War 1972). 


\section{References}

Abdullah, Zain. 2010. Black Mecca: The African Muslims of Harlem. Oxford: Oxford University Press.

Aidi, Hisham. 2014. Rebel Music: Race, Empire, and the New Muslim Youth Culture. New York: Vintage.

Alim, H. Samy. 2006. Roc the Mic Right: The Language of Hip Hop Culture. New York: Routledge.

Appadurai, Arjun. 1988. "Introduction: Place and Voice in Anthropological Theory." Cultural Anthropology 3 (1): 16-20.

Asad, Talal. 1986. The Idea of an Anthropology of Islam. Occasional Papers Series.

Washington, DC: Center for Contemporary Arab Studies, Georgetown University.

-1993. Genealogies of Religion: Discipline and Reasons of Power in Christianity and Islam. Baltimore, MD: Johns Hopkins University Press.

- 2003. Formations of the Secular: Christianity, Islam, and Modernity. Stanford, CA: Stanford University Press.

Bogira, Steve. 2011. "Separate, Unequal and Ignored." Chicago Reader, February 10, 2011, 1317.

Bourdieu, Pierre. 1977. Outline of a Theory of Practice. Cambridge: Cambridge University Press.

Burdick, John. 2013. The Color of Sound: Race, Religion, and Music in Brazil. New York: New York University Press.

Cainkar, Louise. 2005. "Space and Place in the Metropolis: Arabs and Muslims Seeking Safety." City \& Society 17 (2): 181-209. 
Chan-Malik, Sylvia. 2011. “'Common Cause': On the Black-Immigrant Debate and Constructing the Muslim American.” Journal of Race, Ethnicity, and Religion 2 (8): 1-39.

Chang, Jeff. 2005. Can't Stop Won't Stop: A History of the Hip-Hop Generation. New York: Picador.

Clay, Andreana. 2012. The Hip-Hop Generation Fights Back: Youth, Activism and Post-Civil Rights Politics. New York: New York University Press.

Curtis, Edward E. 2014. The Call of Bilal: Islam in the African Diaspora. Chapel Hill: University of North Carolina Press.

Daulatzai, Sohail. 2012. Black Star, Crescent Moon: The Muslim International and Black Freedom beyond America. Minneapolis: Univers ity of Minnesota Press.

Davila, Arlene. 2004. Barrio Dreams: Puerto Ricans, Latinos, and the Neoliberal City. Berkeley: University of California Press.

De Certeau, Michel. 2011. The Practice of Everyday Life. Translated by Stephen F. Rendall. Berkeley: University of California Press.

De Genova, Nicholas, and Ana Yolanda Ramos-Zayas. 2003. Latino Crossings: Mexicans, Puerto Ricans, and the Politics of Race and Citizenship. New York: Routledge.

Deeb, Lara. 2006. An Enchanted Modern: Gender and Public Piety in Shi’i Lebanon. Princeton, NJ: Princeton University Press.

- 2009. "Piety Politics and the Role of a Transnational Feminist Analysis." Journal of the Royal Anthropological Institute 15 (S1): S112-26.

Deeb, Lara, and Mona Harb. 2013. Leisurely Islam: Negotiating Geography and Morality in Shi'ite South Beirut. Princeton, NJ: Princeton University Press.

Dyson, Michael Eric. 1997. Between God and Gangsta Rap: Bearing Witness to Black Culture. 
New York: Oxford University Press.

Floyd-Thomas, Juan. 2003. "A Jihad of Words: The Evolution of African American Islam and Contemporary Hip-Hop.” In Noise and Spirit: The Religious and Spiritual Sensibilities of Rap Music, edited by Anthony B. Pinn, 49-70. New York: New York University Press. Forman, Murray. 2002. The 'Hood Comes First: Race, Space, and Place in Rap and Hip-Hop. Middletown, CT: Wesleyan University Press.

Gazzah, Miriam. 2010. "Maroc-Hop: Music and Youth Identities in the Netherlands." In Being Young and Muslim: New Cultural Politics in the Global South and North, edited by Asef Bayat and Linda Herrera, 309-23. Oxford: Oxford University Press.

Grandmaster Flash and the Furious Five. 1982. Single. Produced by Ed Fletcher, Clifton "Jiggs" Chase, and Sylvia Robinson. Sugar Hill Records. Audio CD.

Gregory, Steven. 1999. Black Corona: Race and the Politics of Place in an Urban Community. Princeton: Princeton University Press.

Grewal, Zareena A. 2009. "Marriage in Colour: Race, Religion and Spouse Selection in Four American Mosques.” Ethnic and Racial Studies 32 (2): 323-45.

- 2013. Islam Is a Foreign Country: American Muslims and the Global Crisis of Authority. New York: New York University Press.

Gupta, Akhil, and James Ferguson. 1992. 'Beyond 'Culture': Space, Identity, and the Politics of Difference." Cultural Anthropology 7 (1): 6-23.

Hill, Marc Lamont. 2009. Beats, Rhymes, and Classroom Life: Hip-Hop Pedagogy and the Politics of Identity. New York: Teachers College Press.

Hirschkind, Charles. 2009. The Ethical Soundscape: Cassette Sermons and Islamic Counterpublics. New York: Columbia University Press. 
Inner-City Muslim Action Network. 2007. Takin'It to the Streets program booklet. Chicago: Inner-City Muslim Action Network.

Inskeep, Steve. 2006. "Between Faith and Country: Muslims in America." National Public Radio, September 11, 2006. http:/www.npr.org/templates/story/story.php?storyId56041929.

Jackson, John, Jr. 2003. Harlemworld: Doing Race and Class in Contemporary Black America. Chicago: The University of Chicago Press.

-2005. Real Black: Adventures in Racial Sincerity. Chicago: University of Chicago Press. Jackson, Sherman A. 2005. Islam and the Blackamerican: Looking Toward the Third Resurrection. Oxford: Oxford University Press.

James, Frank. 1966. "Martin Luther King, Jr. in Chicago.” Chicago Tribune, August 5, 1966.

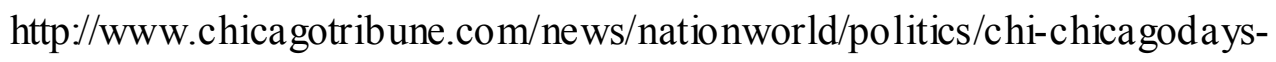
martinlutherking-story-story.html.

Jouili, Jeanette. 2015. Pious Practice and Secular Constraints: Women in the Islamic Revival in Europe. Stanford, CA: Stanford University Press.

Karim, Jamillah. 2008. American Muslim Women: Negotiating Race, Class, and Gender within the Ummah. New York: New York University Press.

Khabeer, Su'ad Abdul. 2016. Muslim Cool: Race, Religion and Hip Hop in the United States. New York: New York University Press.

Kitwana, Bakari. 2006. Why White Kids Love Hip Hop: Wankstas, Wiggers, Wannabes, and the New Reality of Race in America. New York: Basic Civitas Books.

Knott, Kim. 2005. "Spatial Theory and Method for the Study of Religion.” Temenos 41 (2): 15384. 
Kwon, Soo Ah. 2013. Uncivil Youth: Race, Activism, and Affirmative Governmentality. Durham, NC: Duke University Press.

Lefebvre, Henri. 1991. The Production of Space. Oxford: Blackwell.

Low, Setha M. 2000. On the Plaza: The Politics of Public Space and Culture. Austin: University of Texas Press.

—. 2009a. "Maintaining Whiteness: The Fear of Others and Niceness." Transforming Anthropology 17 (2): 79-92.

_ 2009b. "Toward an Anthropological Theory of Space and Place." Semiotica 175:21-37.

Low, Setha M., and Denise Lawrence-Zuniga. 2003. The Anthropology of Space and Place: Locating Culture. Malden, MA: Wiley-Blackwell.

Mahmood, Saba. 2005. Politics of Piety: The Islamic Revival and the Feminist Subject. Princeton, NJ: Princeton University Press.

Maira, Sunaina. 2008. "B-Boys and Bass Girls: Sex, Style and Mobility in Indian American Youth Culture." In Desi Rap: Hip-Hop and South Asian America, edited by Ajay Nair and Murali Balaji, 41-70. Lanham, MD: Lexington Books.

Massey, Douglas S., and Nancy A. Denton. 1993. American Apartheid: Segregation and the Making of the Underclass. Cambridge, MA: Harvard University Press.

Miller, Monica R. 2013. Religion and Hip Hop. New York: Routledge.

Mitchell, Tony, ed. 2002. Global Noise: Rap and Hip Hop Outside the USA. Middletown, CT: Wesleyan University Press.

Miyakawa, Felicia. 2005. Five Percenter Rap: God Hop's Music, Message, and Black Muslim Mission. Bloomington: Indiana University Press.

Nair, Ajay, and Murali Balaji, eds. 2008. Desi Rap: Hip-Hop and South Asian America. Lanham, 
MD: Lexington Books.

Nashashibi, Rami. 2005. "IMAN \& Critical Engagement." Unpublished document. Photocopy provided by Rami Nashashibi.

- 2007. "The Blackstone Legacy: Islam and the Rise of Ghetto Cosmopolitanism." Souls 9 (2): $123-31$.

Pardue, Derek. 2011. Brazilian Hip Hoppers Speak from the Margins: We's on Tape. New York: Palgrave Macmillan.

Parsons, Monique. 2011. 'New Mosques Cropping Up in Chicago, Study Shows.” National Public Radio, November 3, 2011. http//www.npr.org/2011/11/03/ 141945254/newmosques-cropping-up-in-chicago-study-shows.

Pattillo-McCoy, Mary. 2000. Black Picket Fences: Privilege and Peril among the Black Middle Class. Chicago: University of Chicago Press.

Peterson, James Braxton. 2014. The Hip-Hop Underground and African American Culture: Beneath the Surface. New York: Palgrave Macmillan.

Pinn, Anthony B., ed. 2003. Noise and Spirit: The Religious and Spiritual Sensibilities of Rap Music. New York: New York University Press.

Ralph, Laurence. 2014. Renegade Dreams: Living through Injury in Gangland Chicago. Chicago: London: University of Chicago Press.

Razack, Sherene. 2008. Casting Out: The Eviction of Muslims from Western Law and Politics. Toronto, ON: University of Toronto Press.

Rodman, Margaret. 1992. "Empowering Place: Multilocality and Multivocality." American Anthropologist 94 (3): 640-56.

Rose, Tricia. 1994. Black Noise: Rap Music and Black Culture in Contemporary America. 
Hanover, Germany: Wesleyan University Press.

Schielke, Samuli. 2009. "Being Good in Ramadan: Ambivalence, Fragmentation, and the Moral Self in the Lives of Young Egyptians." Journal of the Royal Anthropological Institute 15 (S1): S24-40.

Sharma, Nitasha Tamar. 2010. Hip Hop Desis: South Asian Americans, Blackness, and a Global Race Consciousness. Durham, NC: Duke University Press.

Sorett, Josef. 2009. “'Believe Me, This Pimp Game Is Very Religious': Toward a Religious History of Hip Hop." Culture and Religion 10 (1): 11-22.

South Suburban Housing Center. 2008. Still Separate and Unequal: The State of Fair Housing in America. Written Testimony for the National Commission on Fair Housing and Equal Opportunity. Homewood, IL: South Suburban Housing Center.

Spady, James, and Joseph Eure. 1991. Nation Conscious Rap: The Hip Hop Vision. Philadelphia, PA: PC International Press.

Swedenberg, Ted. 1997. "Islam in the Mix: Lessons of the Five Percent." Paper presented at Anthropology Colloquium, University of Arkansas, Fayetteville, AR, February 19. —. 2010. 'Fun^Da^Mental's 'Jihad Rap'.” In Being Young and Muslim: New Cultural Politics in the Global South and North, edited by Asef Bayat and Linda Herrera, 291307. Oxford: Oxford University Press.

Taylor, Jennifer Maytorena, dir. 2009. New Muslim Cool. Specific Productions, DVD. Los Angeles, CA: Seventh Art Releasing.

Utley, Ebony. 2012. Rap and Religion: Understanding the Gangsta's God. Santa Barbara, CA: Praeger.

Vasquez, Manuel, and Kim Knott. 2014. "Three Dimensions of Religious Place Making in 
Diaspora." Global Networks 14 (3): 326-47.

Wang, Oliver. 2007. "Rapping and Repping Asian: Race, Authenticity and the Asian American MC." In Alien Encounters: Popculture in Asian America, edited by Mimi Tu Nguyen and Thuy Linh Nguyen Tu, 35-68. Durham, NC: Duke University Press.

War. 1972. The World is a Ghetto. Produced by Howard E. Scott. New York: United Artists Records, vinyl.

Werbner, Pnina. 1996. "Stamping the Earth with the Name of Allah: Zikr and the Sacralizing of Space among British Muslims.” Cultural Anthropology 11 (3): 309-38. 